\title{
IMPACT OF FEEDING GUAR PLANT AS SILAGE OR HAY FOR ZARAIBI DOES IN TWO REPRODUCTIVE STAGES ON NEWBORN PERFORMANCE AND SOME BLOOD AND METABOLIC PARAMETERS. Mohamed, E.A. ; M.E. El-Kholany ; W.M.A. Sadek and A. L. I. Desoky \\ Animal Production Research Institute, Agricultural Research Center, Dokki, Giza, Egypt.
}

Key Words: Goat, guar, silage, hay, late pregnancy - suckling.

\section{ABSTRACT}

This study aimed to study effects of using Guar plant as silage (GS) or hay $(\mathrm{GH})$ in feeding Egyptian Zaraibi does during the late pregnancy and suckling periods on growth parameters, and some rumen and blood parameters. The roughage was $40 \%$ corn silage (CS), $30 \%$ $\mathrm{GS}+30 \% \mathrm{CS}$, and $30 \% \mathrm{GH}+30 \% \mathrm{CS}$ in ration of $\mathrm{G} 1, \mathrm{G} 2$, and $\mathrm{G} 3$, respectively. Results indicated that daily DM intake as BW\% and $\mathrm{g} / \mathrm{kgw}^{0.75}$ was higher during suckling period than at late pregnancy in all groups. The ruminal NH3-N and TVFA's concentrations were affected $(\mathrm{P}<0.05)$ by feeding and reproductive stage. Only RBCs and MCHC was the highest $(\mathrm{P}<0.05)$ in $\mathrm{G} 3$ and the lowest $(\mathrm{P}<0.05)$ in $\mathrm{G} 2$, being lower at late pregnancy than at suckling. Globulin was highest and creatinine and ALP were lowest in G3 $(\mathrm{P}<0.05)$. Total proteins, globulin, calcium, phosphorus, manganese were higher $(\mathrm{P}<0.05)$ during suckling than at late pregnancy. Birth and weaning weights, daily gain, and crop of born kids were the highest $(\mathrm{P}<0.05)$ in $\mathrm{G} 3$. The mortality rate was $30,23.8$, and $9.1 \%$ in G1, G2, and G3, respectively. Values of economic feed efficiency was $1.85,2.35$, and 2.55 in G1, G2, and G3, respectively. It could be concluded that using Guar silage or Guar hay as partial replacement of concentrate feed mixture in Zaraibi does rations during late pregnancy and suckling period had a positive impacts on born kids performance and production of viable kids at weaning. This strategy has a good economic return on the herd of Zaraibi goats.

\section{INTRODUCTION}

Nutrition is a major factor affecting the physiological and metabolic statuses, and consequently the productive performance of farm animals. In Egypt, there is wide gap between the available feed stuffs and the nutritional requirements of animal population. During summer season, green forages with reasonable protein contents are not adequately available. Guar (Cyamopsis tetragonoloba) is a multi-purpose plant, most 
used today as a source of galactomannan gum, which is used as a stabilizer in foods such as salad dressings, ice cream and yoghurt. The gum and the water soluble resin extracted from seeds are also use in other industries, including paper manufacturing, cosmetics, mining and oil drilling (Wong and Parmar, 1997). Guar was found to be not very suitable for grazing due to its hairy leaves and unpalatability (Göhl, 1982), but Guar is sometimes grazed to reduce the risk of blot in ruminants (Wong and Parmar, 1997). Palatability improves after cutting and wilting (Göhl, 1982). The best time for cutting Guar for fodder is during flowering and early pod formation (Wong and Parmar, 1997). In goats, Guar hay cut a pod formation gave better nutrient and energy intakes and digestabilities than the mixture of Guar hay and crushed oats (Pachauri and Upadhyaya 1986).

In this respect, Guar plant was choosing to study the possibility of using as silage or hay in feeding pregnant Egyptian Zaraibi does during the late pregnancy and suckling periods on production performance and some metabolic parameters of does and their newborn kids..

\section{MATERIALS AND METHODS}

This study was conducted at El-Serw Experimental Research Station belongs to Animal Production Research Institute, Agricultural Research Center, Ministry of Agriculture, Egypt.

Thirty lactating Zaraibi does in the $2^{\text {nd }}, 3^{\text {rd }}$ and $4^{\text {th }}$ seasons of lactation, and weighing on averaged $40.0 \mathrm{~kg}$ were divided according to their body weight into 3 similar groups (10 does in each group). The experimental groups were fed three experimental rations, included control (G1): $60 \%$ CFM $+40 \%$ corn silage (CS), the second group (G2): $40 \% \mathrm{CFM}+30 \%$ Guar silage $(\mathrm{GS})+30 \% \mathrm{CS}$ and the third group (G3): $40 \% \mathrm{CFM}+30 \%$ Guar hay $(\mathrm{GH})+30 \% \mathrm{CS}$. All does were at the late pregnancy period ( $4^{\text {th }}$ months of pregnancy) and feeding period continued for 90 days after kidding (at weaning). Animals were weighed at the beginning and biweekly as transition period on the same ration before the start of the experiment.

The nutrients were calculated to cover dairy goats requirements according to NRC (1981). Concentrate feed mixture (CFM) consisted of $43 \%$ yellow corn, undecortecated cotton meal (25\%), wheat bran $(25 \%)$, molasses $(3.5 \%)$, limestone $(2 \%)$, common salt $(1.0 \%)$ and minerals mixture $(0.5 \%)$. The chemical composition of different feed stuffs was determined (Table 1), water was available all times and drinking water was measured for each group (ml/day). Diets were offered twice daily at 8 a.m. and 3 p.m. and any refused amounts were daily recorded. Approximate chemical analysis of the feeds was carried out according to A.O.A.C (1995). 
Table (1): Chemical analysis of feeds and experimental rations during the late pregnancy and suckling periods.

\begin{tabular}{|c|c|c|c|c|c|c|c|}
\hline \multirow{2}{*}{ Feeds } & \multirow{2}{*}{ DM\% } & \multicolumn{7}{|c|}{ Chemical composition \% on DM basis } \\
\cline { 3 - 8 } & & OM & CF & CP & EE & NFE & Ash \\
\hline CFM & 90.50 & 93.60 & 15.60 & 14.50 & 3.40 & 60.10 & 6.40 \\
\hline CS & 33.50 & 91.00 & 28.80 & 9.30 & 3.20 & 49.70 & 9.00 \\
\hline GS & 35.50 & 86.50 & 26.30 & 14.65 & 2.50 & 43.05 & 13.50 \\
\hline GH & 85.50 & 83.00 & 12.00 & 21.00 & 2.30 & 47.70 & 17.00 \\
\hline \multicolumn{7}{|c|}{ Chemical composition of experimental rations during the late pregnancy } \\
\hline G1 & 62.80 & 90.40 & 23.45 & 12.10 & 2.65 & 52.20 & 9.60 \\
\hline G2 & 61.50 & 89.50 & 23.60 & 12.81 & 2.90 & 50.19 & 10.50 \\
\hline G3 & 62.50 & 90.30 & 23.30 & 14.92 & 2.95 & 49.13 & 9.70 \\
\hline \multicolumn{7}{|c|}{ Chemical composition of experimental rations during the suckling period } \\
\hline G1 & 62.90 & 90.30 & 23.65 & 12.00 & 2.60 & 52.05 & 9.70 \\
\hline G2 & 62.00 & 89.45 & 23.70 & 12.75 & 2.95 & 50.05 & 10.55 \\
\hline G3 & 63.30 & 90.50 & 23.20 & 14.90 & 3.00 & 49.40 & 9.50 \\
\hline
\end{tabular}

CFM: Concentrate feed mixture (25\% undecortecated cottonseed meal, $43 \%$ yellow corn, $25 \%$ wheat bran, $3.5 \%$ molasses, $2 \%$ limestone, $1 \%$ common salt and $0.5 \%$ minerals mixture).

Rumen fluid samples were taken from 3 animals of each experimental group using stomach tube at 02,4 and $6 \mathrm{~h}$ post-feeding during the end of feeding trails. The samples were filtered through 3 layers of gauze and $\mathrm{pH}$ was immediately by $\mathrm{pH}$-meter. Ammonia nitrogen $\left(\mathrm{NH}_{3}-\mathrm{N}\right)$ concentration was measured according to Conway (1957). Microbial protein was determined according to Shultz and Shultz (1970), while, concentration of total volatile fatty acids (VFA's) was determined according to the technique described by Warner (1964).

Live body weight of does and their kids was biweekly recorded individually . Litter size (number of kids/doe), kidding rate (litter size $\times$ 100) and mortality rate were also calculated.

Blood samples were taken once during last month of pregnancy and the first month of lactation from 3 does of each group via the jugular vein just before feeding. Blood sample of each doe was collected into two test tubes, the $1^{\text {st }}$ contained EDTA as anticoagulant, while another test tube without anticoagulant. The $1^{\text {st }}$ tube was taken as whole blood, and immediately used for hematological estimation. Another tube of the blood sample was centrifuged at $4000 \mathrm{rpm}$ for 20 minutes to separate serum, which was frozen at $-20^{\circ} \mathrm{C}$ until analyses for enzyme activity, biochemicals, minerals and hormonal determination . Commercial kits were used for all blood measures.

Data were statistically analyzed by factorial design of ANOVA $(3 \times 2)$ to study the effect of the experimental rations, reproductive stage, and their interaction on different parameters studied using SAS (2003). The analyzed data are presented as means and SEM. 


\section{Feed intake:}

\section{RESULTS AND DISCUSSION}

At late pregnancy stage, daily dry matter intake relative to LBW or metabolic body weight was slightly higher in G1 than in G2 and G3. The same trend was observed with daily DM intake during suckling period.The daily DM intake expressed as BW\% and $\mathrm{g} / \mathrm{kgw}^{0.75}$ during the suckling periods was higher than that consumed during the late pregnancy period in all ration (Table 2). The observed increase in roughage intake as a silage denotes that silage was of good quality as reported by Ahmed et al. (2001 and 2013) with lactating goats.

Generally, there are many factors affecting chemical composition as species (legume and grass), soil, fertilization, subsequent, cuts, age and environmental condition (Gabra et al., 1991; Khinizy et al., 1997; Haggag et al, 2000; and Soliman \& Haggag, 2002).

Table (2): Daily dray mater intake (DMI) by Zaraibi does during the two experimental periods.

\begin{tabular}{|c|c|c|c|}
\hline \multirow{2}{*}{ Items } & \multicolumn{3}{|c|}{ Groups } \\
\hline & G1 & G2 & G3 \\
\hline \multicolumn{4}{|c|}{ Daily dray mater intake (g/h) during the late pregnancy period* } \\
\hline From CFM & 820 & 540 & 530 \\
\hline From CS & 546 & 405 & 400 \\
\hline From GS & $\mathbf{0}$ & 405 & $\mathbf{0}$ \\
\hline From GH & $\mathbf{0}$ & $\mathbf{0}$ & 390 \\
\hline Total DMI & 1366 & 1350 & 1320 \\
\hline DMI, \% BW & 3.42 & 3.38 & 3.30 \\
\hline DMI, g/kg w ${ }^{0.75}$ & 85.91 & 84.90 & 83.02 \\
\hline \multicolumn{4}{|c|}{ Daily dray mater intake $(\mathrm{g} / \mathrm{h})$ during the suckling period* } \\
\hline From CFM & 870 & 600 & 585 \\
\hline From CS & 580 & 710 & 420 \\
\hline From GS & $\mathbf{0}$ & 415 & $\mathbf{0}$ \\
\hline From GH & $\mathbf{0}$ & $\mathbf{0}$ & 400 \\
\hline Total DMI & 1450 & 1425 & 1405 \\
\hline DMI, \% BW & 3.63 & 3.56 & 3.51 \\
\hline DMI, g/kg w ${ }^{0.75}$ & 91.20 & 89.62 & 88.36 \\
\hline
\end{tabular}

* Group feeding.

\section{Water consumption:}

Data of water consumption of Zaraibi does during pregnancy and suckling periods are presented in Table (3). The differences in water consumption among the experimental groups were slight, but water consumption increased at the suckling period as compared to at late pregnancy, especially in G3 (Table 3). Generally, the quantity of daily water consumption in present study is nearly similar to those obtained by Soliman et al. (2010) on growing Zaraibi goats (ranged from 2.22 to $3.30 \mathrm{ml} / \mathrm{g}$ DM intake) and Ahmed et al. (2013) on lactating Zaraibi goats (ranged from 2.82 to $3.06 \mathrm{ml} / \mathrm{g} \mathrm{DM}$ intake). 
Table (3): Daily water consumption by Zaraibi does during the two experimental periods.

\begin{tabular}{|c|c|c|c|}
\hline \multirow{2}{*}{ Item } & \multicolumn{3}{|c|}{ Experimental groups } \\
\hline & G1 & G2 & G3 \\
\hline \multicolumn{4}{|c|}{ Water consumption during the late pregnancy period* } \\
\hline Liter/head/day & 3.85 & 3.90 & 4.00 \\
\hline $\mathbf{m l} / \mathbf{k g ~ B W}$ & 96 & 98 & 100 \\
\hline $\mathrm{ml} / \mathrm{kg} \mathrm{w}^{0.75}$ & 242 & 245 & 251 \\
\hline $\mathrm{ml} / \mathrm{g}$ DMI & 2.82 & 2.89 & $\mathbf{3 . 0 3}$ \\
\hline \multicolumn{4}{|c|}{ Water consumption during the suckling period* } \\
\hline Liter/head/day & 5.20 & 5.35 & $\mathbf{5 . 5 0}$ \\
\hline $\mathbf{m l} / \mathbf{k g ~ B W}$ & 130 & 133 & 138 \\
\hline $\mathrm{ml} / \mathrm{kg} \mathrm{w}^{0.75}$ & 327 & 336 & 345 \\
\hline $\mathrm{ml} / \mathrm{g}$ DMI & 3.58 & 3.75 & 3.91 \\
\hline
\end{tabular}

* Group feeding.

\section{Ruminal fermentation parameters:}

Concerning the effect of the experimental rations, reproductive stage and their interaction on ruminal parameters indicated that the minimum $\mathrm{pH}$ values and the maximum total VFA's values were recorded $3 \mathrm{~h}$ post-feeding. The same trend was obtained by Gabra et al. (1999) and Shehata et al. (2006) on goats, and Sadek (2011) on sheep. Moreover, the ruminal ammonia-N concentrations were greater postfeeding than before-feeding and the maximum values of NH3-N in the ruminal liquor reached at $3 \mathrm{~h}$ post-feeding. At 3 and $6 \mathrm{~h}$ post-feeding, ruminal NH3-N concentrations were significantly higher in the rumen of goats in G2 and G3 than in those G1. The high content of ruminal ammonia-N concentration in G3 may be due to the high content of $\mathrm{CP}$ in silage mixture (Table1). Similar results were observed by Ahmed et al. (2001), Shehata et al. (2006) and Ibrahim et al. (2012) with Zaraibi goats fed rations containing kochia, reed and sesbania silages, respectively. Also, El-Kholany (2004) found that the NH3-N was higher in the rumen of goats fed sesbania silage and silage mixture (sesbania+ maize) than those fed maize silage only; this may be attributed to high content of $\mathrm{CP}$ in sesbania silage and high protein degradability of sesbania protein as reported by Khalili and Varikko (1992).

Ruminal total VFA's concentrations showed the highest values 3 and $6 \mathrm{~h}$ post-feeding in G3 (12.40 and $11.45 \mathrm{mEq} / 100 \mathrm{ml}$, respectively), while the lowest values were detected in G1 (12.03 and 11.09 $\mathrm{mEq} / 100 \mathrm{ml}$, respectively). This differences were significant. Similar results were observed by El-Kholany (2004), who reported that the highest values of ruminal TVFA's were recorded with silage mixture (sesbania+ maize) at all hours, and then maize silage and lowest values 
were detected with sesbania silage group. The decrease in TVFA's during the late pregnancy, may be due to the decrease in daily feed intake per $\mathrm{kgw}^{0.75}$ and/or response to the physiological stress of pregnancy. The same result was observed by Sadek (2011) with Rahmani ewes during late pregnancy and suckling periods. Generally, it seems that ruminal VFA's showed an opposite trend of ruminal NH3-N, since both were affected by physiological status (Table 4).

Table (4): The effect of experimental rations on some rumen parameters of Zaraibi does during the two experimental periods.

\begin{tabular}{|c|c|c|c|c|c|c|c|c|c|c|}
\hline \multirow{2}{*}{\multicolumn{2}{|c|}{ Item }} & \multicolumn{3}{|c|}{ pH } & \multicolumn{3}{|c|}{ NH3 (mg/100ml RL) } & \multicolumn{3}{|c|}{ TVF's (meq./ 100ml RL) } \\
\hline & & $\mathbf{0}$ & 3 & 6 & $\mathbf{0}$ & 3 & 6 & $\mathbf{0}$ & 3 & 6 \\
\hline \multicolumn{2}{|l|}{ G1 } & 6.90 & 6.50 & 6.70 & 16.32 & $21.05^{\mathrm{bc}}$ & $20.00^{b}$ & 9.10 & $\mathbf{1 2 . 0 3}^{\mathrm{b}}$ & $11.09^{b}$ \\
\hline \multicolumn{2}{|l|}{ G2 } & 6.97 & 6.60 & 6.75 & 16.45 & $21.85^{a b}$ & $21.30^{\mathrm{a}}$ & 9.05 & $12.13^{\mathrm{ab}}$ & $11.22^{\mathrm{ab}}$ \\
\hline \multicolumn{2}{|l|}{ G3 } & 6.95 & 6.55 & 6.80 & 16.60 & $22.30^{\mathrm{a}}$ & $21.55^{\mathrm{a}}$ & 9.02 & $12.40^{\mathrm{a}}$ & $11.45^{\mathrm{a}}$ \\
\hline \multicolumn{2}{|c|}{ SEM } & 0.18 & $\mathbf{0 . 1 0}$ & $\mathbf{0 . 1 2}$ & 0.22 & 0.24 & 0.26 & 0.041 & 0.105 & 0.093 \\
\hline \multicolumn{2}{|c|}{ Sig. } & NS & NS & NS & NS & $*$ & $*$ & NS & $*$ & $*$ \\
\hline \multicolumn{2}{|c|}{ Pregnancy } & 7.00 & 6.60 & 6.81 & 16.60 & 22.14 & $22.00^{\mathrm{a}}$ & 8.95 & $11.94^{b}$ & $10.75^{b}$ \\
\hline \multicolumn{2}{|c|}{ Suckling } & 7.89 & 6.47 & 6.70 & 16.30 & 21.40 & $19.85^{b}$ & 9.21 & $12.12^{\mathrm{a}}$ & $12.20^{a}$ \\
\hline \multicolumn{2}{|c|}{ SEM } & 0.12 & 0.08 & 0.09 & 0.30 & 0.35 & 0.27 & 0.20 & 0.15 & 0.21 \\
\hline \multicolumn{2}{|c|}{ Sig. } & NS & NS & NS & NS & NS & $*$ & NS & $*$ & $*$ \\
\hline \multirow{3}{*}{ Pregnancy } & G1 & 6.96 & 6.59 & 6.78 & 16.50 & 21.23 & 21.42 & 9.00 & 11.70 & 10.62 \\
\hline & G2 & 7.30 & 6.64 & 6.79 & 16.47 & 22.25 & 22.13 & 8.90 & 11.93 & 10.67 \\
\hline & G3 & 7.00 & 6.58 & 6.85 & 16.83 & 22.95 & 22.45 & 8.95 & 12.20 & 10.91 \\
\hline \multirow{3}{*}{ Suckling } & G1 & 6.83 & 6.40 & 6.60 & 16.12 & 20.85 & 18.60 & 9.15 & 11.36 & 11.19 \\
\hline & G2 & 6.93 & 6.54 & 6.70 & 16.43 & 21.45 & 20.45 & 9.20 & 12.40 & 12.65 \\
\hline & G3 & 6.90 & 6.48 & 6.80 & 16.35 & 21.90 & 20.50 & 9.29 & 12.60 & 12.76 \\
\hline \multicolumn{2}{|c|}{ SEM } & 0.24 & 0.16 & 0.17 & 0.58 & 0.71 & 0.55 & 0.39 & 0.30 & 0.42 \\
\hline \multicolumn{2}{|c|}{ Sig. } & $\mathbf{N S}$ & NS & NS & $\mathbf{N S}$ & NS & $\mathbf{N S}$ & NS & $\mathbf{N S}$ & $\mathbf{N S}$ \\
\hline
\end{tabular}

a-c: Means at the same column with different letters are significantly $(\mathrm{P}<0.05)$ different.

NS: Non-significant.

\section{Blood parameters:}

\section{Hematological parameters:}

Data of hematological parameters of does fed different experimental rations during late pregnancy and suckling periods are presented in Table (5). Results indicated that only RBCs and MCHC were affected significantly by the experimental ration or reproductive stage, being significantly the highest in G3 and the lowest in G1, and during suckling than at late pregnancy, However, most hematological parameters were not affected significantly by the experimental ration or reproductive stage (Table 5).

The observed reduction in the values of the erythrogram (RBCs and MCHC) at late pregnancy as compared to during suckling may be attributed to the mild stress of pregnancy as reported by Schalm (1961), 
Ahmed (1999) and Sadek (2011). These findings are in agreement with those reported by Hafez et al. (1983), who observed that some hematological parameters such as $\mathrm{Hb}, \mathrm{MCHC}$ and RBC's decreased with the advance of pregnancy especially during the last week and thereafter tended to increase after parturition till they approach the values of the control group (non pregnant and non lactation) 6 weeks post- partum. The same trend was observed by El-Fadaly and Radwan (1992) for hematocrit value and $\mathrm{Hb}$. In general, the obtained data indicate that all estimated values for measured parameters are within the normal range of Zaraibi goats as reported by Ahmed et al. (2008).

Table (5): The effect of experimental rations on some hematological parameters of Zaraibi does during the two experimental periods.

\begin{tabular}{|c|c|c|c|c|c|c|c|c|c|c|c|c|}
\hline \multicolumn{2}{|l|}{ Item } & $\begin{array}{c}\text { Hb } \\
(\mathrm{g} / \mathrm{dl})\end{array}$ & $\begin{array}{l}\text { Het } \\
(\%)\end{array}$ & $\begin{array}{c}\text { RBC's } \\
\left(\times 10^{3} / \mathbf{u l}\right)\end{array}$ & $\begin{array}{c}\text { MCV } \\
\text { (Fl) }\end{array}$ & $\begin{array}{c}\text { MCH } \\
(\mathbf{P g})\end{array}$ & $\begin{array}{c}\text { MCHC } \\
(\%)\end{array}$ & $\begin{array}{c}\text { WBC's } \\
\left(\times 10^{3} / \mathbf{u l}\right)\end{array}$ & $\begin{array}{l}\text { Lympho } \\
\text { Cyst, }(\%)\end{array}$ & \begin{tabular}{|c|} 
Nutro \\
Phils, $\%$ )
\end{tabular} & $\begin{array}{l}\text { Meuo } \\
\text { Cyst, } \\
(\%)\end{array}$ & $\begin{array}{l}\text { Platlets } \\
\left(\times 10^{3} / \mathbf{u l}\right)\end{array}$ \\
\hline \multicolumn{2}{|l|}{ G1 } & 10.80 & 35.30 & $13.45^{c}$ & 20.80 & 5.70 & $30.10^{\mathrm{c}}$ & 10.26 & 55.63 & 37.30 & 5.90 & 450 \\
\hline \multicolumn{2}{|l|}{ G2 } & 11.00 & 35.10 & $13.80^{b}$ & 19.80 & 6.30 & $32.04^{b}$ & 10.07 & $\mathbf{5 7 . 8 0}$ & 36.30 & 5.65 & 466 \\
\hline \multicolumn{2}{|l|}{ G3 } & 11.33 & 34.20 & $14.10^{a}$ & 19.90 & 6.40 & 33.30 ${ }^{\mathrm{a}}$ & 10.03 & 63.12 & 34.00 & 5.73 & 495 \\
\hline \multicolumn{2}{|l|}{ SEM } & 0.35 & 0.93 & 0.25 & 0.60 & 0.40 & 0.55 & 0.37 & 2.60 & 2.56 & 0.60 & 14.20 \\
\hline \multicolumn{2}{|l|}{ Sig. } & NS & NS & * & NS & NS & $*$ & NS & NS & NS & NS & NS \\
\hline \multicolumn{2}{|c|}{ Pregnancy } & 10.62 & 34.75 & $13.38^{b}$ & 20.03 & 6.00 & $30.47^{\mathrm{b}}$ & 10.21 & 58.31 & 36.83 & 5.83 & 457 \\
\hline \multicolumn{2}{|c|}{ Suckling } & 11.04 & 34.90 & $13.95^{\mathrm{a}}$ & 20.13 & 6.23 & $32.00^{\mathrm{a}}$ & 10.05 & 59.43 & 34.80 & 5.68 & 485 \\
\hline \multicolumn{2}{|l|}{ SEM } & 0.24 & 0.68 & 0.17 & 0.40 & 0.24 & 0.39 & 0.28 & 1.80 & 1.75 & 0.43 & 10.05 \\
\hline \multicolumn{2}{|l|}{ Sig. } & NS & NS & $*$ & NS & NS & * & NS & NS & NS & NS & NS \\
\hline \multirow{3}{*}{ Pregnancy } & G1 & 10.45 & 35.40 & 12.92 & 20.80 & 5.50 & 29.42 & 10.30 & 54.63 & 38.30 & 6.00 & 438 \\
\hline & \begin{tabular}{|l|} 
G2 \\
\end{tabular} & 10.40 & 34.85 & 13.45 & 19.70 & 6.20 & 29.54 & 10.17 & 56.30 & 37.20 & 5.75 & 456 \\
\hline & G3 & 11.00 & 34.00 & 13.76 & 19.60 & 6.30 & 32.46 & 10.15 & 64.00 & 35.00 & 5.73 & 478 \\
\hline \multirow{3}{*}{ Suckling } & G1 & 10.08 & 35.20 & 13.28 & 20.70 & 5.80 & 30.78 & 10.27 & 56.63 & 36.20 & 5.82 & 461 \\
\hline & G2 & 11.36 & 35.10 & 14.15 & 19.70 & 6.50 & 31.07 & 9.97 & 59.30 & 35.20 & 5.53 & 480 \\
\hline & G3 & 11.68 & 34.40 & 14.43 & 20.00 & 6.40 & 34.13 & 9.92 & 62.35 & 33.00 & 5.70 & 513 \\
\hline \multicolumn{2}{|l|}{ SEM } & 0.48 & 1.36 & 0.34 & 0.80 & 0.48 & 0.78 & 0.56 & 3.60 & 3.50 & 0.86 & 20.10 \\
\hline \multicolumn{2}{|l|}{ Sig. } & NS & NS & NS & NS & NS & NS & NS & NS & NS & NS & NS \\
\hline
\end{tabular}

a-c: Means at the same column with different letters are significantly $(\mathrm{P}<0.05)$ different.

NS: Non-significant.

\section{Biochemical parameters:}

Data of biochemical parameters of does fed different experimental rations during late pregnancy and suckling periods are presented in Table (6). Serum concentration of globulin and phosphorus significantly increased, while creatinine concentration and ALP activity significantly decreased in G2 and G3 compared with G1. As affected by the reproductive stage, total proteins, globulin, calcium, phosphorus, manganese were higher $(\mathrm{P}<0.05)$ during suckling than at late pregnancy. In comparable with the present results, Ahmed (1999) showed that serum total proteins, globulin, urea-N, creatinine, uric acid, total lipids, cholesterol and magnesium as well as thyroid hormones concentrations were higher at the last month of pregnancy than in the lactation months. 
Table (6): The effect of experimental rations on some biochemical parameters of Zaraibi does during the $\tilde{\sigma}$ two experimental periods.

\begin{tabular}{|c|c|c|c|c|c|c|c|c|c|c|c|c|c|c|c|c|c|}
\hline \multicolumn{2}{|c|}{ Item } & 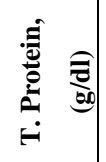 & 氧 & 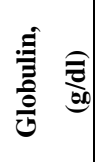 & 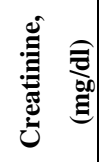 & 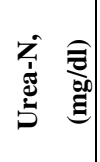 & 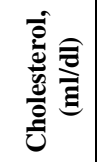 & 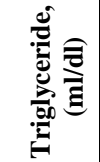 & $\begin{array}{l}\widehat{\Xi} \\
\hat{5} \\
\frac{5}{4}\end{array}$ & 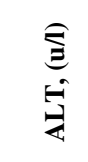 & 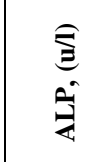 & $\Leftrightarrow$ 音 & $\pm \quad \begin{array}{c}\hat{\bar{\theta}} \\
\mathrm{g}\end{array}$ & 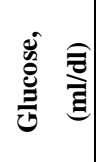 & 氖 & 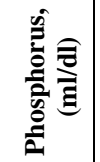 & 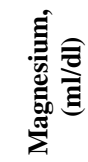 \\
\hline \multicolumn{2}{|c|}{ G1 } & 6.20 & 3.75 & $2.45^{\mathrm{b}}$ & $0.93^{\mathrm{a}}$ & 16.83 & 91.20 & 49.20 & 75.20 & 23.00 & $123.50^{\mathrm{a}}$ & 118.20 & 6.80 & 57.00 & 9.50 & $4.30^{b}$ & 2.50 \\
\hline \multicolumn{2}{|l|}{ G2 } & 6.35 & 3.48 & $2.87^{\mathrm{a}}$ & $0.83^{\text {ab }}$ & 15.70 & 88.80 & 46.30 & 69.50 & 20.80 & $110.20^{b}$ & 122.30 & 6.65 & 56.80 & 9.65 & $4.65^{\mathrm{ab}}$ & 2.70 \\
\hline \multicolumn{2}{|l|}{ G3 } & 6.46 & 3.56 & $2.90^{\mathrm{a}}$ & $0.75^{\mathrm{b}}$ & 15.83 & 90.83 & 47.00 & 69.85 & 20.65 & $109.70^{b}$ & 127.33 & 6.70 & 58.75 & 9.80 & $5.00^{\mathrm{a}}$ & 2.63 \\
\hline \multicolumn{2}{|c|}{ SEM } & 0.20 & 0.14 & 0.10 & 0.06 & 0.40 & 2.60 & 2.57 & 3.52 & 1.44 & 2.50 & 7.10 & 0.46 & 3.90 & 0.34 & 0.15 & 0.16 \\
\hline \multicolumn{2}{|c|}{ Sig. } & NS & NS & $*$ & $*$ & NS & NS & NS & NS & NS & $*$ & NS & NS & NS & NS & $*$ & NS \\
\hline \multicolumn{2}{|c|}{ Pregnancy } & $6.15^{\mathrm{b}}$ & 3.40 & $2.75^{\mathrm{b}}$ & $0.94^{\mathrm{a}}$ & 16.39 & $96.23^{\mathrm{a}}$ & 49.68 & 72.06 & 21.78 & $121.40^{\mathrm{a}}$ & $159.77^{\mathrm{a}}$ & $7.48^{\mathrm{a}}$ & 55.96 & $9.19^{\mathrm{b}}$ & $4.32^{\mathrm{b}}$ & $2.21^{\mathrm{b}}$ \\
\hline \multicolumn{2}{|c|}{ Suckling } & $6.50^{\mathrm{a}}$ & 3.65 & $2.85^{\mathrm{a}}$ & $0.82^{\mathrm{b}}$ & 15.93 & $84.99^{b}$ & 45.53 & 71.68 & 21.21 & $106.43^{b}$ & $84.13^{b}$ & $5.91^{\mathrm{b}}$ & 59.80 & $10.15^{\mathrm{a}}$ & $4.97^{\mathrm{a}}$ & $3.10^{\mathrm{a}}$ \\
\hline \multicolumn{2}{|c|}{ SEM } & 0.12 & 0.09 & 0.08 & 0.05 & 0.28 & 1.84 & 1.83 & 2.47 & 1.04 & 1.72 & 5.00 & 0.34 & 2.76 & 0.25 & 0.10 & 0.12 \\
\hline \multicolumn{2}{|l|}{ Sig. } & * & NS & $*$ & * & NS & $*$ & NS & NS & NS & $*$ & $*$ & $*$ & NS & $*$ & $*$ & * \\
\hline \multirow{3}{*}{ Pregnancy } & G1 & 5.94 & 3.58 & 2.36 & 1.02 & 17.08 & 97.00 & 51.35 & 77.20 & 23.70 & 131.00 & 156.00 & 7.75 & 59.65 & 9.06 & 4.00 & 2.15 \\
\hline & G2 & 6.13 & 3.37 & 2.76 & 0.93 & 16.00 & 95.00 & 48.00 & 69.00 & 21.30 & 117.20 & 157.00 & 7.25 & 53.63 & 9.20 & 4.40 & 2.30 \\
\hline & G3 & 6.38 & 3.24 & 3.14 & 0.86 & 16.10 & 96.70 & 49.70 & 70.00 & 20.35 & 116.00 & 166.30 & 7.45 & 54.60 & 9.30 & 4.55 & 2.18 \\
\hline \multirow{3}{*}{ Suckling } & G1 & 6.40 & 3.84 & 2.56 & 0.86 & 16.58 & 85.67 & 47.30 & 75.00 & 22.33 & 115.00 & \begin{tabular}{|l|}
81.40 \\
\end{tabular} & 5.85 & 56.30 & 10.05 & 4.50 & 2.95 \\
\hline & G2 & 6.60 & 3.60 & 3.00 & 0.83 & 15.62 & 84.30 & 45.00 & 70.35 & 20.30 & 103.00 & 81.70 & 6.05 & 60.00 & 10.10 & 4.95 & 3.25 \\
\hline & G3 & 6.50 & 3.50 & 3.00 & 0.76 & 15.60 & 85.00 & 44.30 & 69.70 & 21.00 & 101.30 & 89.30 & 5.83 & 63.10 & 10.30 & 5.45 & 3.10 \\
\hline \multicolumn{2}{|c|}{ SEM } & 0.24 & 0.18 & 0.16 & 0.10 & 0.56 & 3.68 & 3.66 & 4.94 & 2.08 & 3.44 & 9.98 & 0.68 & 5.52 & 0.50 & 0.21 & 0.24 \\
\hline \multicolumn{2}{|c|}{ Sig. } & NS & NS & NS & NS & NS & NS & NS & NS & NS & NS & NS & NS & NS & NS & NS & NS \\
\hline
\end{tabular}


Generally, the obtained data of most serum biochemicals of does in the experimental groups are within the normal range as reported by Kaneko (1989), Maged (2004) Sadek (2011) and Ahmed et al. (2012) for small ruminants.

\section{Live body weight of does:}

Table (7) showed that changes in live body weight (LBW) of Zaraibi goats. The LBW of does increased to the maximum before parturition and recorded the highest values (ranged from 48.6 to $49.8 \mathrm{~kg}$ ) then sharply decreased post- parturition to the minimum at day $90^{\text {th }}$ (weaning) in all groups. The same trend was observed by Ahmed et al. (2012) with Zaraibi does at the late pregnancy and during the lactation period. Also, Shehata et al. (2007) observed that the LBW of does increased to the maximum weight before parturition (end of pregnancy) and recorded the highest values $(55.7-58.8 \mathrm{~kg})$, decreased during postpartum to the minimum values during suckling period, then slightly increased in during the lactation period. Similar results were observed by El-Shinnawy et al. (2010) with Rahmani ewes during the late pregnancy and suckling periods.

Table (7): Live body weight change $(\mathrm{kg})$ of Zaraibi does during the two experimental periods.

\begin{tabular}{|c|c|c|c|}
\hline Days & \multicolumn{3}{|c|}{ Groups } \\
\cline { 2 - 4 } & G1 & G2 & G3 \\
\hline $\begin{array}{c}\text { Initial weight (at 90 days of } \\
\text { pregnancy) }\end{array}$ & 40.2 & 40.0 & 43.8 \\
\hline At 120 days of pregnancy & 43.4 & 43.8 & 49.8 \\
\hline $\begin{array}{c}\text { At 150 days of pregnancy (last } \\
\text { month) }\end{array}$ & 48.6 & 49.10 & 41.3 \\
\hline Weight at kidding & 40.0 & 40.3 & 39.4 \\
\hline Weight at 30 days post kidding & 38.6 & 38.9 & 39.0 \\
\hline Weight at 60 days post kidding & 37.4 & 38.0 & 92.1 \\
\hline Weight at 90 days post kidding & 36.3 & 36.8 & 92.25 \\
\hline
\end{tabular}

\section{Productive performance:}

Data of the productive performance of Zaraibi does fed on the tested experimental rations are summarized in Table (8). The results indicated that no abortion cases happened during the late eight weeks of pregnancy. The obtained data showed that the still birth cases were noticeably higher in G1 (15\%) compared with the other groups. From data in Table (8) it seems that incidence of twins parturition was high in Zaraibi does fed G3 compared with other groups, hence, the kidding rate or litter size was high too. Moreover, kidding rates were 200, 210 and 
220 in G1, G2 and G3 respectively. Similar values for litter size of Zaraibi does were obtained by Mousa (1996), Ahmed (1999) and Maged (2012).

The present study indicated that does given Guar hay (G3) or Guar silage (G2) during late pregnancy period gave born kids with heavier weight at the birth and weaning $(1.90,1.67$ and $10.65,9.98 \mathrm{~kg}$, respectively) compared with G1 (1.50 and $9.30 \mathrm{~kg}$, respectively) and the differences were significant as shown in Table (8). Accordingly, output measured as kilograms produced per doe and economic feed efficiency were better with G3, followed by G2 and lastly G1. These positive effects may be attributed to high content of CP in Guar silage and Guar hay.

The percentage of mortality recorded the highest values in control group $(30 \%)$ then $\mathrm{G} 2(23.80 \%)$ whereas mortality rate was $(9.10 \%)$ in G3. Similar results were observed by El- Hosseiny et al. (2000) who observed that using medical herbs such as chamomile flowers in doe diets reduced mortality rate of born kids to zero during the suckling period compared with rate of 6.67 to $13.33 \%$ for other medicinal herbs.

Table (8): The effect of experimental rations on reproductive performance and economic efficiency of Zaraibi does.

\begin{tabular}{|c|c|c|c|}
\hline \multirow{2}{*}{ Item } & \multicolumn{3}{|c|}{ Experimental group } \\
\hline & G1 & G2 & G3 \\
\hline Number of does & 10 & 10 & 10 \\
\hline Does with single kids (\%) & 30 & 20 & 20 \\
\hline Does with twin kids (\%) & 40 & 50 & 40 \\
\hline Does with triple kids (\%) & 30 & 30 & 40 \\
\hline Total number of born kids & 20 & 21 & 22 \\
\hline Litter size/doe & 2 & 2.1 & 2.2 \\
\hline Kidding rate & 200 & 210 & 220 \\
\hline Still birth & 3 & 2 & $\mathbf{0}$ \\
\hline Alive kids at 0 days & 17 & 19 & 22 \\
\hline Alive kids at 15 days & 16 & 18 & 21 \\
\hline Alive kids at 30 days & 16 & 18 & 21 \\
\hline Alive kids at 45 days & 15 & 17 & 21 \\
\hline Alive kids at 60 days & 14 & 16 & 20 \\
\hline Alive kids at 90 days & 14 & 16 & 20 \\
\hline $\begin{array}{l}\text { Average kid weight at birth } \\
\text { (kg) }\end{array}$ & $1.50 \pm 0.08^{b}$ & $1.67 \pm 0.10^{\mathrm{ab}}$ & $1.90 \pm 0.10^{\mathrm{a}}$ \\
\hline $\begin{array}{l}\text { Average kid weight at } \\
\text { weaning }(\mathrm{kg})\end{array}$ & $9.30 \pm 0.30^{b}$ & $9.98 \pm 0.28^{a b}$ & $10.65 \pm 0.47^{\mathrm{a}}$ \\
\hline Average daily gain $(\mathrm{kg} / \mathrm{h} / \mathrm{d})$ & $86.67 \pm 4.40^{b}$ & $92.33 \pm 1.86^{\mathrm{ab}}$ & $97.22 \pm 2.46^{a}$ \\
\hline Kid crop (kg) /doe at birth & $3.75 \pm 0.27$ & $4.14 \pm 0.60$ & $4.60 \pm 0.45$ \\
\hline Kid crop $(\mathrm{kg}) / \mathrm{doe}$ at weaning & $25.62 \pm 1.95^{b}$ & $27.12 \pm 2.90^{\text {ab }}$ & $27.95 \pm 2.55^{a}$ \\
\hline Number of dead kids & 6 & 5 & 2 \\
\hline Mortality rate of kids & 30 & 23.80 & 9.10 \\
\hline Economic efficiency & $\mathbf{1 . 8 5}$ & 2.35 & 2.55 \\
\hline
\end{tabular}

a-b: Means at the same row with different letters are significantly $(\mathrm{P}<0.05)$ different. 


\section{CONCLUSION}

It could be concluded that using Guar silage or Guar hay as partial replacement of concentrate feed mixture in Zaraibi does rations during late pregnancy and suckling periods had a positive impacts on improving some metabolic parameters and reproductive performance, without any adverse effect on the general health. This improvement was reflected on born kids performance and production of viable kids at weaning. This had a good economic strategy in the management of Zaraibi goat heds. Further studies are needed to evaluate the Guar forage in different forms (hay- fresh - silage) at different levels as well as with other sources of energy and feed additive with different farm animals.

\section{REFERENCES}

A.O.A.C. (1995). Official Methods of Analysis (16th Edit). Association of Official Analytical Chemists, Washington, D.C., USA.

Ahmed, M.E. (1999). Improving feed conversion efficiency during reproduction-stress-phases. Ph.D. Thesis, Fac. Agric., Mansoura Univ.

Ahmed, M.E.; A.M. Abdelhamid ; F.F. Abou Amou ; E.S. Soliman ; N.M. El-Kholy and E.I. Shehata (2001). Response of milk production of Zaraibi goats to feeding silage containing different levels of teosinte and kochia. Egyptian J. Nutrition and Feeds, (4): 141.

Ahmed, M.E. ; E.I. Shehata ; F.F. Abou Ammou ;A.M. AbdelGowad and K. M. Aiad (2008). Milk production feed conversion rate and reproduction of Zaraibi goat in response to bacterial feed additive during late pregnancy and lactation. Egypt. J. Anim. Prod., 45: 189.

Ahmed, M.E. ; E.I. Shehata ; G.H.M. Zaza ; A.M. Abdel-Gawad ; E.I. Khalifa and K.M. Aiad (2012). Milk production, feed conversion ratio and reproduction of Zaraibi goats fed reed plants in different forms during late pregnancy and lactation periods. 11th Conf. Agric. Dev. Res., Fac. Agric., Ain Shams Univ., Cairo, Egypt.

Ahmed, M.E. ; E.I. Shehata ; M.E. El-Kholany ; G.I. El-Emam ; E.I. Khalifa and H. Bahery (2013). Productive performance of Zaraibi goats fed berseem and/or triticale silage. The 4th Scientific Conference of Animal Production Research Institute, P: 184. 
Conway, E.F.(1957). Micro diffusion Analysis and Volumetric Error. Rev. Ed. Lock Wood, London.

El- Hosseiny, H. M.; S.M. Allam ; S. A. El-Saadany ; A. M. AbdelGawad and A.M. M. Zeid (2000). Medicinal herbs and plants as feed additives for ruminants. 2-Effect of using some medicinal herbs on growth performance of Zaraibi kids. Proc. Conf. Anim. Prod. Sakha, Kafr ElSheikh, 18-20 April, P: 189.

El-Fadaly, A. and Y. A. Radwan (1992). The effect of pregnancy, parturition and lactation on electrolytes and blood picture, as well as liver and kidney function in Buffaloes. J. Egypt. Vet. Med. Ass., 52 (1): 105.

El-Kholany, M.M. (2004). Evaluation of some new green fodder for Farm animals.Ph.D. Thesis Fac. of Agric, Mansoura Univ.

El-Shinnawy, M.M. ; M. E. Ahmed and W.M.A. Sadek (2010). Effect of some feeding schemes on some rumen parameters, blood profile and productive performance of Rahmani sheep. J. Animal and Poultry Prod., Mansoura Univ. 1(10):481.

Gabra, A.A.; A.M. Abdelhamid and M.Y. EI-Ayek (1991). Nutritional evaluation of dried poultry litter in comparison with berseem hay (Trifolium alexandrinum) and their mixtures as feeds for sheep. J. Agric. Sci.. Mansoura Univ., 16 (9) : 2004 - 2016.

Gabra, A.A. ; A.Z. Mehrez ; E.S.M. Soliman and M.El-Kholany (1999). Response of lactating goats to diets containing reed grass (Aroundo domax L.) versus sorghum plants, Egyptian J. Nutrition and feeds, 2 (Special Issue): 297.

Göhl, B. (1982). Les aliments du bétail sous les tropiques. FAO, Division de Production et Santé Animale, Roma, Italy.

Hafez, A.M. ; H. Ibrahim ; A. Gomaa ; A.A. Farrag and I.A. Salem (1983). Enzymatic and hematological studies on buffaloes at preparturient periods. Assiut Vet. Med. J., 11 (21): 172.

Haggag, M. El-H. ; E.S. Soliman ; E.M. Gaafer and M.I. Salem (2000). Effect of phosphate fertilizer levels and seeding rates on yield, quality and nutritional evaluation of Sesbania forage by goats. J. Agric. Sci. Mansoura Univ., 25 (7): 3901

Ibrahim, F.A. ; E.S. Soliman ; A. A. Abd El-Hamid and M. E. Ahmed (2012). Growth performance and feed utilization efficiency of Rahmani lambs fed some legume and /or grass silages. Egyptian J. of Sheep and Goats Sciences, 7 (2): 1. 
Kaneko, J.J. (1989). Clinical Biochemistry of Animals. 4thEd., Academic Press, Inc. USA.

Khalili, H. and T. Varvikko (1992). Effect of replacement of concentrate mix by wilted Sesbania (Sesbania Sesban) forage on diet digestibility, rumen fermentation and milk production in Friezian x Zebu (Boran) cross bred cows fed low quality native hay. Anim. Feed Sci. and Technol., 63: 275.

Khinizy, A.E.M. ; M.K., Hathout ; W.H. Abdel-Malik ; S.I. Hafez and P.A. Aspila (1997). Evaluation of some summer forages cultivated in new reclaimed sandy soil in Egypt. J. Agric. Sci. Mansoura Univ., 22 (8):2565.

Maged, G.A. (2004). Nutritional studies on small ruminants M.Sc. Thesis. Fac. of Agric., Mansoura Univ., Egypt.

Maged, G.A. (2012). Effect of medical herbs on production of dairy Zaraibi goats. Ph. D. Thesis, Fac. of Agric., Mansoura Univ., Egypt.

Mousa, M.M. (1996). Physiological and nutritional studies on goats. Ph.D. Thesis, Fac. Agric., Mansoura Univ.

NRC (1981).Nutrient Requirements of Domestic Animals. Nutrient Requirements of Goats. National Research Council, Washington, D.C. USA, of Official Analytical Chemists, Washington, D.C., USA.

Pachauri, V.C. and R.S. Upadhyaya (1986). Nutritive value of clusterbean (Cyamopsis tetragonoloba) hay as affected by supplementation of oat grain in goats. Indian J. Anim. Sci., 56 (1): $154-155$

Sadek, W.M.A. (2011). Nutritional requirements of rahmani ewes. Ph.D. Thesis, Fac. Agric., Mansoura Univ.

SAS Institute (2003). SAS/STATR User's Guide: statistics. Ver. 9.1, SAS Institute Inc., Cary, NC, USA.

Schalm, O.W.(1961). Veterinary Hematology . 1st Ed. Bailler, Tindall and Cow , london.

Shehata, E.I. ; F.H. Abd El-Rasoul ; F.F. Abou Ammou ; M.E. Ahmed and A.M. Abdel-Gawad (2007). Effect of feeding the medicinal herbs, chamomile flower, on some productive performance of Egyptian Zaraibi does and their new born kids. Egypt. J. of Sheep and Goats Sci., 2:111.

Shehata, E.I. ; M.E. Ahmed ; Faten F. AbouAmmou ; A.A.M. Soliman ; K.M. Aiad and A.M. Abdel-Gawad (2006). 
Comparison of feeding reed as hay or silage with feeding berseem hay or Maize silage to dairy Zaraibi goats. Egyptian Sheep Goats and Desert Animals Sci., 1(1): 233-247.

Shultz, T.A. and E. Shultz (1970). Estimation of rumen microbial nitrogen by three analytical methods. J. Dairy Sci., 53:781.

Soliman, A. A. ; M. E. Ahmed ; Faten F. Abou Ammou ; E.I. Shehata ; M.K. Abou Elmaged ; S.A. Tawfik and M. A. Shebl (2010). Impact of some feed additives on Zaraibi goats performance and blood profile fed aflatoxins contaminated diets. AmericanEurasian J. Agric. And Erviron Sci., 7 (1) : 80.

Soliman, E.S. and M.EI-H. Haggag (2002). Effect of feeding green forage mixtures of Sesbania and Teosinte instead of concentrate feed mixture on lactating goats. Egypt. J. Appl. Sci., 17 (5): 31.

Warner, A.C.I. (1964). Production of volatile fatty acids in the rumen, methods of measurements. Nutr. Abst. \& Rev., 34: 339.

Wong, L.J. and C. Parmar (1997). Cyamopsis tetragonoloba (L.) Taubert. Record from Proseabase. Faridah Hanum, I \& van der Maesen, L.J.G. (Eds). PROSEA (Plant Resources of South-East Asia) Foundation, Bogor, Indonesia.

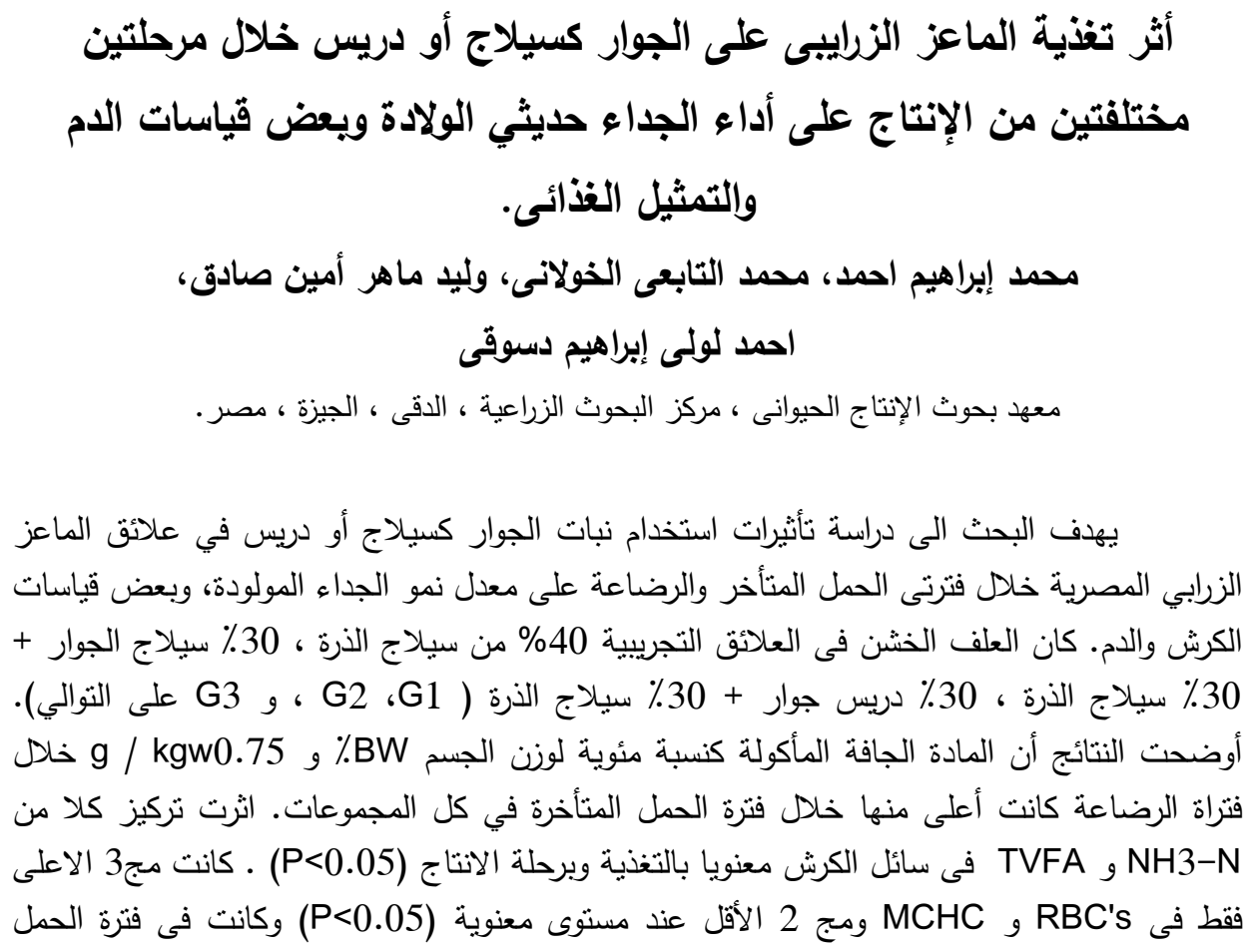




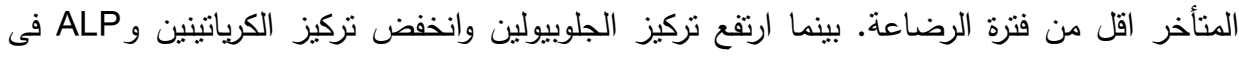

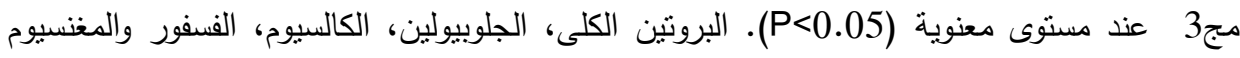

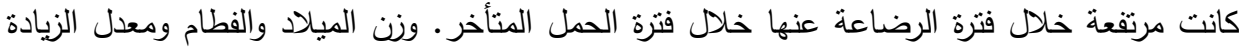

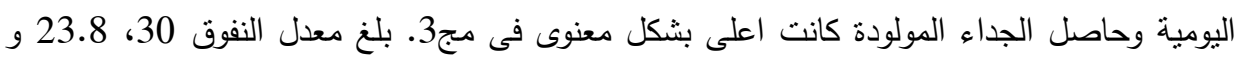

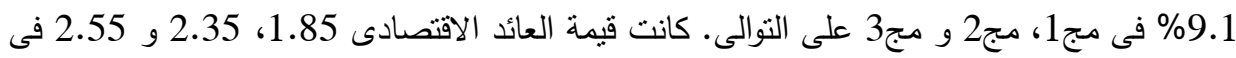

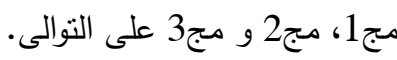

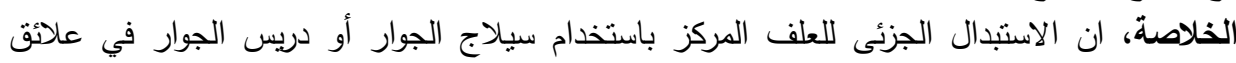

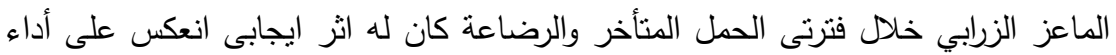

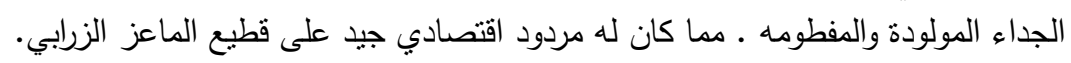

